\title{
University Students' Opinions on Effects of Reading Habit on Academic Success and Self-Improvement
}

\author{
Aysun Dogutas \\ Dept. of Educational Sciences, Pamukkale University \\ Kınıklı Kampüsü, Denizli, Turkey \\ Tel: 90-506-600-3114Ｅ-mail: adogutas@pau.edu.tr
}

Received: June 14, 2019 Accepted: July 14, 2019 Published: July 16, 2019

doi: 10.5296/ire.v7i2.15106 URL: https://doi.org/10.5296/ire.v7i2.15106

\begin{abstract}
Since we are living at knowledge age and have a society which has been shaped by knowledge, reading is an essential tool for knowledge transfer and the habit of reading is an academic activity that increases skills in reading strategies. Reading habit is very important for people especially for university students. In this study, university students' opinions about the reading habit and its' effects on self-improvement and academic success will be examined. Descriptive model of quantitative research was used as a research model. The sample of the study is 248 university students at Education Faculty, Pamukkale University in Turkey. The results of the study showed that university students believe that reading habit increases their self and academic success. The results also showed that there is a difference between female and male students' opinions about self-improvement and academic success depending on reading habit.
\end{abstract}

Keywords: Self-improvement, Academic success, Reading habit

\section{Introduction}

Since we are living at knowledge age and have a society which is been shaped by knowledge, it can be said that reading habit is a social element that will provide knowledge- individual and knowledge-society relation. Reading is a basis of knowledge acquisition. Reading is the ability to understand words contained in a document and make use of the knowledge for personal growth and development (Dadzie, 2008). Reading is an essential tool for knowledge transfer and the habit of reading is an academic activity that increases skills in reading strategies. Children, who miss the opportunity of getting in touch with books in their early stages of life, find it hard to acquire good reading habits in their later yearsi (Deavers, 2000). 
Reading habit is defined as "individual's carrying out reading act as lifelong, continuously, regularly and critically; as a result of perceiving reading as a need and source of enjoy (Y1lmaz, 1993). An act's being a habit isn't easy. To be able to practice that act regularly and continuously is hard. Reading's being a habit is also hard for people especially for young people. This habit can be gained during school years especially during elementary and secondary school years. There are many elements affecting individual's reading habit. These elements can be divided into two as individual and social elements.

Good reading habits act as a strong weapon for the students to excel in life (Bashir \& Mattoo, 2012).Reading habit determines the academic achievement of students to a great extent. Both reading and academic achievements are dependent on each other and interrelated. Students have different levels of academic achievement because they often come from different environments and localities. Therefore, they differ in the pattern of reading habits. Reading is an exciting voyage to self-discovery and makes way for a better understanding of one's own experiences. "Reading habit is best formed at a young impressionable age in school, but once formed it can last one's life time (Greene, 2001). But we shouldn't ignore the importance of family, school and close environment of children while forming reading habit (Solmaz, 2018). According to Palani (2012), effective reading is important avenue of effective learning and reading is interrelated with the total educational process and hence, educational success requires successful reading habit. Palani (2012) further added that reading habit has lost its importance as both the young and the old are glued to the television. Most students' problem that contributes to their poor performance in tests and examinations is lack of proper reading habits. There is the need for the student to form good reading and study habits for an excellent performance. Researchers and academicians, conducting studies on reading, regard reading and reading activities as the most invaluable and indispeansable elements in the lifelong learning process for there is an essential correlation between reading habits and academic success (Korkmaz, Aras, Çelebi, \& Gürkan, 2015).

As well as classic aim and scope of higher education institutions such as education and training and training qualified manpower, universities should undertake some responsibilities such as doing research; produce, spread and protect knowledge; being leader of the society; and molding public opinion. Since university youth will be society's elite, executive and thinking individuals, they should be raised conscious and qualified in this sense. University student should be professional. There isn't any other natural thing than to expect university students', who will shape our future, having reading habit (Çoban, İleri, \& Temir, 2018). University student isn't a living just studying lessons and memorizing knowledge. These students should be an individual, who researches, argues, producing ideas; thus can be a learning individual. To be able to create a healthy society, reading habit, which is very important for every individual of the society, is more important for university students. Because university youth form intelligentsia of that country (Turcan, Yıldırım, \& Kelleci, 1999, s. 184).

\subsection{Previous Studies}

Since reading is very important there are many studies done on reading habit in Turkey and 
around the World. In the following part studies done on reading habit will be presented.

The study sought to assess the reading habits among students and their effects on their academic performance in Koforidua Polytechnic situated in the Eastern Region of Ghana by Owusu-Acheaw (2014). The study confirmed that reading habit has influence on academic performance and there is a relationship between reading habit and academic performance. Similar to this study, Annamalai and Muniandy (2013) studied the reading habit and attitude of the students in a Malaysian Polytechnic. Results of the study revealed that; (i) the polytechnics students have low interest in reading; (ii) students do not enjoy reading as much as they enjoy doing other technology related activities.

Similar to the studies around the World, there are many studies done on reading habit level. In a study done at Middle East Technical University in 2000 showed that \%21,6 of university students had reading habit (Gömleksiz, 2004). When we looked at the study of Gazi University students, results revealed that only $\% 37$ of the students prefer reading books and magazines out of course activities (Yazıc1, 2001). According to survey results of applied to seniors at 46 Physical Education and Sports Teaching Departments at 40 different universities showed that students don't read. Causes of students' not reading books out of course activities are television's being attractive, high costs of books, high loaded program, disliking reading, lack of guidance and etc. (Semerci, 2002). Yaylalı et al. (2006)'s study showed that approximately $58 \%$ of students read book often or always, $39 \%$ of students sometimes and less frequently and only $3 \%$ of them never read books. From the study of Odabaş, Odabaş and Polat (2008), it can be understood that approximately half of the students participated to the study either never read book or read maximum 5 books. According to a study done in 1993 by Ministry of National Education, youths' 61\% didn't read any book for the last one month, $13.4 \%$, read only one book. Another study showed that reading rates of university youth's was only $37.1 \%$. This shows that people who will raise our next generations don't have a reading habit. Geçgel and Burgul (2009) asked students if they take time off reading in their studies and most of the students stated that they don't spend not enough time on reading.

In addition to reading habit level studeis, there are some attitudes studies done in Turkey but these studies don't focus one reading habit attitudes only. For example, Temizkan and Sallabaş (2009) study compared the attitudes of teacher candidates related to reading and writing activities. İşeri and Ünal (2012)'s study also focused on writing and reading attitudes. The aim of this research was to investigate the impact of teacher candidates' reading and writing attitudes on their academic achievements.

\subsection{Problem Statement}

Many parents and teachers complain about students of our generation who have not developed reading habits among themselves. Nowadays, due to the influence of the mass media, people do not show much interest in reading books; magazines and journals, among others (Palani, 2012). Especially students prefer to watch movies and other shows on the television, listening to audio-CDs, watching video-CDs, among others (Issa et al., 2012). The overall result of Annamalai and Muniandy (2013)' study indicates that Malaysian polytechnic students spend quite a significant amount of time surfing the Internet, playing 
computer/mobile games and other technology-related activities compared to reading. Perhaps, due to lack of good reading habits among students, academic performance is creating a great source of worry and concern for all stakeholders in the educational area (Issa et al., 2012).

Similar to the studies around the World, studies done in Turkey also showed that even if there have been important changes in Turkish society within social, economic and political circumstances, Turkish people are not on good terms with books, newspapers and journals and Turkish society don't bring reading as a habit and lifestyle. As discussed above there are many studies done in turkey about the level of reading habit (Gömleksiz, 2004; Yazıc1, 2001; Yaylalı et al., 2006; Odabaş, Odabaş \& Polat, 2008). There are many studies done on reading habits of students both in Turkey and around the World. These studies focused on the choice of students about reading and the level of students' reading habits. However, there are many few studies focusing on reasons of not reading and opinions of students' about reading habit and its effects on self-improvement and academic lives. This study aimed ot fill this gap.

\subsection{Aim of the Study}

Previous studies showed that university students don't read enough book and they don't have a good reading habit. Reading habit settled into at early ages of an individual, however it is a habit that affects whole life of a person. Thus, reading habit is very important for people especially for university students. To be able to understand what you read, analyze, critic, and transfer knowledge, one should read more and more which yields self-improvement and academic success. A person should improve oneself to be able to have a good place in a society and academic achievement is a must for professional life. In this study, university students' opinions about the reading habit and its' effects on self-improvement and academic success will be examined. Additional research questions are as follows; a) is there any difference between female and male students opinions about effect of reading habit on self-improvement; and b) is there any difference between female and male students opinions about effect of reading habit on academic success.

\section{Method}

In this section, research model, sample of the study, data collection and analysis processes will be presented.

\subsection{Research Model}

This study, aiming to determine Pamukkale University Education Faculty students' opinions about reading habit and its' effects on self-improvement and academic success, is based on descriptive model of quantitative research. "Desriptive models are research approaches aimed to describe a present or past situation as so. Subjects of a research such as a phenomenon, an individual or an object are tried to be described within its' own circumstances and as it is. There is no effort to change or affect them anyhow (Karasar, 2000, 77).

\subsection{Population and Sample}

Population of the study is all students of Pamukkale University, Faculty of Education students. The total number of students at Faculty of education is 22,345 at present (2018-2019 
academic years). According to survey's 0.95 reliance and 0.05 tolerance level, sample of whole bachelor students should be 230 (Çıng1, 1990, s. 256). By taking into consideration of missing surveys 248 surveys were applied to students. Thus, the sample of the study is 248 university students at Pamukkale University, Education Faculty.

248 participants were participated to the study. 168 of the participants' were female $(65.7 \%)$ and 81 were male (32.7\%) and 4 (51.6) was missing (See Table 1).

Table 1. Gender of participants

\begin{tabular}{llll}
\hline & Frequency & Percent \\
\hline Valid & .00 & 4 & 1.6 \\
& Female & 163 & 65.7 \\
& Male & 81 & 32.7 \\
& Total & 248 & 100.0 \\
\hline
\end{tabular}

Participants of the study were from different departments of Education Faculty. 138 (55.6\%) of them were studying at psychological counseling and guidance department, $55(22.2 \%)$ at mathematics and 55 (22.2\%) of them at English teaching department (See Table 2).

Table 2. Department of participants

\begin{tabular}{llll}
\hline & Frequency & Percent \\
\hline Valid & Pcg & 138 & 55.6 \\
& Math & 55 & 22.2 \\
& English & 55 & 22.2 \\
& Total & 248 & 100.0 \\
\hline
\end{tabular}

\subsection{Data Collection Tool}

As a data collection tool 5 point likert scale survey was used. "Attitude Scale Towards Reading Habit" developed by Gömleksiz (2004), was used. 30 items were chosen for the scale and there were 21 positive, 9 negative attitude items in the scale. Cronbach Alpha reliability coefficient of the scale was found as .88 . There were 6 dimensions of the scale. Since teh aim of this study was only determine the reading habit opinions and its effects on self-development and aademic success, 10 questions related to these dimensions were chosen.

\subsection{Realibility of the Current Study}

In terms of the reliability of the questionnaire in total and each item separately, the reliability test of Coefficient Alpha (Cronbach's alpha) was conducted. The Cronbach's Alpha level was .862 which shows that the survey was reliable. At the end of reliability analysis 10 items 


\section{Macrothink

were used for evaluation. These ten items were divided into two as; the first 5 are related to self-improvement and the rest is related to academic success.

\subsection{Data Collection Process}

Data was collected at fall semester of 2018-2019 academic years. Surveys were applied to students at the end of course time at classrooms they have been thought. Participants were told that participation to the study is based on voluntary basis and they had a chance to reject to participate. Some students went out and the rest filled in questionnaires. Application of survey lasted almost half an hour.

\subsection{Data Analysis}

SPSS 17 was used to analyze the data. To analyze the data these statistical processes were used; for descriptive statistics of personal features frequency (f) and percent (\%) technics, and for describing relations correlation and test technics were used. These will be presented step by step in the following section.

\section{Findings}

In this section, frequencies of each question will be presented. Later correlations and t test results will be given. Results of the study are as follows;

Table 3. Question 6: Reading helps expressing feelings easier

\begin{tabular}{lll}
\hline & Frequency & Percent \\
\hline Totally disagree & 2 & .8 \\
Disagree & 3 & 1.2 \\
Partially agree & 14 & 5.6 \\
Agree & 69 & 27.8 \\
Totally agree & 160 & 64.5 \\
Total & 248 & 100.0 \\
\hline
\end{tabular}

Most of the students agree that reading makes expressing feelings easier. $64.5 \%$ of them were totally agreed while $27.8 \%$ of them agree. There were very few students who were disagree (see Table 3). 
Table 4. Question 7: Reading provides understanding others and whole World

\begin{tabular}{lll}
\hline & Frequency & Percent \\
\hline Totally disagree & 1 & .4 \\
Disagree & 4 & 1.6 \\
Partially agree & 9 & 3.6 \\
Agree & 70 & 28.2 \\
Totally agree & 164 & 66.1 \\
Total & 248 & 100.0 \\
\hline
\end{tabular}

Again most of the students were agree with this sentence. $164(\% 66.1)$ were totally agree while $70(\% 28.2)$ of them were agree. Only $5(\% 2)$ of all students were disagree (See Table 4).

Table 5. Question 8 : Reading creates multiple thinking skills

\begin{tabular}{lll}
\hline & Frequency & Percent \\
\hline Totally disagree & 1 & .4 \\
Disagree & 2 & .8 \\
Partially agree & 9 & 3.6 \\
Agree & 62 & 25.0 \\
Totally agree & 174 & 70.2 \\
Total & 248 & 100.0 \\
\hline
\end{tabular}

Most of the students think that reading creates multiple thinking skills. $174(70.2 \%)$ are totally agree, $62(25 \%)$ are agree and $9(3.6 \%)$ are partially agree. Only $3(1.2 \%)$ students disagree with this sentence (See Table 5).

Table 6. Question 9: Reading unwraps the unknown World to us

\begin{tabular}{lll}
\hline & Frequency & Percent \\
\hline Missing & 1 & .4 \\
Totally disagree & 1 & .4 \\
Disagree & 2 & .8 \\
Partially agree & 10 & 4.0 \\
Agree & 57 & 23.0 \\
Totally agree & 177 & 71.4 \\
Total & 248 & 100.0 \\
\hline
\end{tabular}

Almost $100 \%$ of participants agreed that reading unwrap the unknown World to us. 244 


\section{Macrothink}

(98.4\%) of all participants are agree with this sentence. Only $3(1.2 \%)$ of participants disagree that reading unwrap the unknown World to them (See Table 6).

Table 7. Question 10: Reading different kinds of books changes our point of view toward life

\begin{tabular}{lll}
\hline & Frequency & Percent \\
\hline Totally disagree & 2 & .8 \\
Disagree & 4 & 1.6 \\
Partially agree & 10 & 4.0 \\
Agree & 55 & 22.2 \\
Totally agree & 177 & 71.4 \\
Total & 248 & 100.0 \\
\hline
\end{tabular}

As previous questions, participants agreed with this sentence. $97 \%$ of the participants think that reading different kinds of books changes their point of view toward life. When we look at in detail, $177(71.4 \%)$ were totally agree, $55(22.2 \%)$ were agree, and $10(4 \%)$ were partially agree (See Table 7).

Table 8. Question 11: Reading book gains us quick thinking habit

\begin{tabular}{lll}
\hline & Frequency & Percent \\
\hline Missing & 1 & .4 \\
Totally disagree & 1 & .4 \\
Disagree & 3 & 1.2 \\
Partially agree & 17 & 6.9 \\
Agree & 80 & 32.3 \\
Totally agree & 146 & 58.9 \\
Total & 248 & 100.0 \\
\hline
\end{tabular}

Unlike previous questions, number of students who are totally agreed, is a little bit low. 146 (58.9\%) of participants were totally agree, 80 (32.3\%) students were agree, 17 (6.9\%) were partially agree, $3(1.2 \%)$ of them were disagree and only $1(0.4 \%)$ of participants was totally disagree with the sentence of reading book gains us quick thinking habit (see Table 8). 
Table 9. Question 12: Reading book improves ability of analysis, syntheses and interpretation

\begin{tabular}{lll}
\hline & Frequency & Percent \\
\hline Totally disagree & 1 & .4 \\
Disagree & 4 & 1.6 \\
Partially agree & 5 & 2.0 \\
Agree & 79 & 31.9 \\
Totally agree & 159 & 64.1 \\
Total & 248 & $100 . .0$ \\
\hline
\end{tabular}

Like other responses, participants agreed with reading book improve ability of analysis, syntheses and interpretation. 159 (64.1\%) students were totally agree, 79 (31.9\%) were agree, and $5(2 \%)$ were partially agree. On the other hand, only $5(2 \%)$ of participants were disagreed with this opinion (see Table 9).

Table 10. Question 13: Reading skill positively affects success on examinations

\begin{tabular}{lll}
\hline & Frequency & Percent \\
\hline Totally disagree & 2 & .8 \\
Disagree & 7 & 2.8 \\
Partially agree & 27 & 10.9 \\
Agree & 75 & 30.2 \\
Totally agree & 137 & 55.2 \\
Total & 248 & 100.0 \\
\hline
\end{tabular}

Totally agree students to this sentence are a bit lower than previous questions. 137 (55.2\%) of the participants were totally agreed. $75(30.2 \%)$ were agree and $27(10.9 \%)$ were partially agree. Disagreed participants were a bit higher than previous questions. 7 (2.8\%) were disagree and $2(0.8 \%)$ were totally disagree with the sentence (See Table 10).

Table 11. Question 14: Regular reading increases academic success

\begin{tabular}{lll}
\hline & Frequency & Percent \\
\hline Totally disagree & 3 & 1.2 \\
Disagree & 6 & 2.4 \\
Partially agree & 33 & 13.3 \\
Agree & 71 & 28.6 \\
Totally agree & 135 & 54.4 \\
Total & 248 & 100.0 \\
\hline
\end{tabular}


Question 14's responses are similar to Question 13. There are 9 (3.6\%) students who are disagree and the rest of the participants $(94.6 \%)$ were agree with regular reading increases academic success.

Table 12. Question 15: Since I don't have reading habit, I have difficulties on exams

\begin{tabular}{lll}
\hline & Frequency & Percent \\
\hline Totally disagree & 65 & 26.2 \\
Disagree & 85 & 34.3 \\
Partially agree & 56 & 22.6 \\
Agree & 21 & 8.5 \\
Totally agree & 21 & 8.5 \\
Total & 248 & 100.0 \\
\hline
\end{tabular}

Even if there are most students who were disagree with this sentence, it is because of the meaning of the sentence. Since the meaning is negative, responses were also negative. However, there are $98(39.6 \%)$ students who were agree that they have difficulties on exams since they don't have reading habit (See Tabel 12).

After frequency results were presented above, $\mathrm{t}$ test analysis statistics will be presented.

Table 13. T test results for reading habit: Comparison of reading habit of female and male students

\begin{tabular}{llllll}
\hline Group & $\mathrm{N}$ & Mean & Std. Deviation & $\mathrm{t}$ & $\mathrm{df}$ \\
\hline Female & 163 & 4.4245 & .41605 & 4.829 & 242 \\
Male & 81 & 4.0889 & .66351 & & \\
\hline
\end{tabular}

After analysis of comparison of self-improvement habit of female and male students, it has been found that there is a difference between male and female students' reading habit $\left(\mathrm{t}_{0.05}\right.$ : $\left.{ }_{242}=4.829\right)$. According to this, female students' reading habit level $(\bar{x}=4.4245)$ is higher than male students' reading habit level $(\bar{x}=4.0889)$ (See table 13).

Table 14. T test results for academic success: Comparison of academic success of female and male students

\begin{tabular}{llllll}
\hline Group & $\mathrm{N}$ & Mean & Std. Deviation & $\mathrm{t}$ & $\mathrm{df}$ \\
\hline Female & 163 & 4.1227 & .50152 & 3.655 & 242 \\
Male & 81 & 3.8346 & .71259 & & \\
\hline
\end{tabular}


After analysis of comparison of academic success of female and male students, it has been found that there is a difference between male and female students' reading habit $(\mathrm{t}$ 0.05: 242 $=$ $3.655)$. According to this, female students' reading habit level $(\bar{x}=4.1227)$ is higher than male students' reading habit level $(\bar{x}=3.8346)$ (see Table 14$)$.

\section{Discussion and Conclusion}

Current study aimed to determine education faculty students' opinions about the reading habit and its' effects on self-improvement and academic success. 248 Pamukkale University Edcuation faculty students were participated to teh study and Attitude Scale Towards Reading Habit" developed by Gömleksiz (2004) was used as a data collection tool. After SPSS analysis, it has been found that university students are aware of the importance of reading and there are differences between female and male students' opinions. Similar to this result, Demir's (2015) study showed that female university students' reading skills and attitudes levels are more positive than male students.

Even though previous studies showed that university students have low reading culture (Odabaş, Odabaş, \& Polat, 2008) and primary education teacher candidates have "avarage" reading habit (Sağlam, Suna \& Çengelci, 2007); it can be said that university students don't have a good reading habit; however, they are aware of the importance of reading for their self-develeopment and academic success according to the findings of this study. Bozpolat (2010)' s study supports this result by indicating that students see readign as a necessity. Frequency results showed that students are mostly agreed that reading hellps them to express themselves easier, understand the world they lived and unwrap the world they don't know. Also reading creates new skills, changes their point of view. The results support the idea "to be able to understand what you read, analyze, critic, and transfer knowledge, one should read more and more which yields self-improvement and academic success". Thus, self-improvement frequency results revealed that eventhough university students don't read too much and they don't have reading habits they believe that reading helps self-improvement. For academic success frequency results again students believe that reading helps them to be successful. For example they agreed that reading skill positively affects success on examinations and regular reading increases academic success. On the other hand, although they are agreed that reading habit increases academic success they couldn't confess that they don't read much. This result can be concluded from the last question of the survey. The half of the students was agreed with the Question 15 "Since I don't have reading habit, I have difficulties on exams". They know the effect of reading but they don't read much that they agreed that they cannot do well on exams since they don't have a reading habit. Owusu-Acheaw ( 2014)' s study confirmed this result by indicating that reading habit has influence on academic performance and there is a relationship between reading habit and academic performance.

When we look at correlation results of the study, t-test results showed that both in academic success and self-improvement female participants have higher mean than males. Thus, this show that female students believe that reading habit is important on self-improvement and academic success more than male students. This shows us that reading is more important for 
female than male students. This result was supoorted by Odabaş, Odabaş and Polat (2008). They also found out that female students spend more time on reading than male students. Also, Demir (2015) concluded in his study that female students love reading books more than male students. On the other hand, tehre are some studies not supporting the results of this study. For example, results of the study of Ünal and İşeri (2012) indicated that students reading and writing attitudes are not significant predictors of their academic achievements.

In short, there are some studies supporting and some not supporting the results of current study. Under any circumstances, reading habit is a must for people. Ther had been many studies done on this issue and should be done more to understand the reasons of not having a reading habit among university students.

In conlusion, university students believe that reading habit increases their self and academic succcess. At this point, there is a problem here. If these students know the reality, then why they don't read or don't have reading habit as previous studies stated such as results of Annamalai and Muniandy's study revealed that students have low interest in reading and students do not enjoy reading as much as they enjoy doing other technology related activities. Responsibility falls into educational experts. Kubis (1996) justifies that students who were read to when they were children have more positive attitudes toward reading than those who were not. Also, Greene (2001) stated that reading habit is best formed at a young impressionable age in school, but once formed it can last one's life time. If reading habit gained at early ages, then the responsibility falls into educationalist and parents. For future studies, the reasons why these students don't read and why they cannot gain reading habit can be studied. Also, studies with educationalist and parents can be done to find out what they do to enure students reading as a habit.

\section{References}

Annamalai, S., \& Muniandy, B. (2013). Reading habit and attitude among Malaysian Polytechnic students. International Online Journal of Educational Sciences, 5(1), 32-41.

Bashir, I., \& Mattoo, N. H. (2012). A Study on Study Habits and Academic Performance Among Adolescents (14-19) years. International Journal of Social Science Tomorrow, 1(5), $1-5$.

Bozpolat, E. (2010). An assessment of prospective teachers' attitudes towards reading habit (Case of Cumhuriyet University Education Faculty). Journal of World of Turks, 2(1), 411-428.

Çıngı, H. (1990). Örnekleme Kuramı. Ankara: Hacettepe Üniversitesi.

Çoban, A., İleri, T., \& Temir, M. (2018). A continuous overview of book reading habits of university students: American University sample. The Journal of Social Science, 5(19). 50-69.

Dadzie, P. S. (2008). Reading for Education: The roles of Libraries. Ghana Library Journal, 20(1), 1-14. https://doi.org/10.4314/glj.v20i1.33978 
Deavers, R. (2000). The Effect of Instruction on Early Non-Word Reading Strategies. Journal of Research in Reading, 23, 267-286. https://doi.org/10.1111/1467-9817.00122

Demir, S. (2015). An evaluation in reading skills and habitudes of undergraduate students. Uluslararası Türkçe Edebiyat Kültür Eğitim Dergisi, 4(4). 1657-1671.

Geçgel, H., \& Burgul, F. (2009). Eğitim fakültesi öğrencilerinin okuma ilgi alanları. TÜBAV Bilim, 2(3), 341-353.

Gömleksiz, M. N. (2004). Kitap okuma alışkanlığına ilişkin bir tutum ölçeğinin geçerlik ve güvenirliği. Fırat Üniversitesi Sosyal Bilimler Dergisi, 14, 185-195.

Greene, B. (2001). Testing Reading Comprehension of Theoretical Discourse with Close. Journal of Research in Reading, 24(1), 32-98. https://doi.org/10.1111/1467-9817.00134

Issa, A. O., Aliyu, M. B., Akangbe, R. B., \& Adedeji, A. F. (2012). Reading Interest and Habits of the Federal Polytechnic Students. International Journal of Learning \& Development, 2(1), 470-486. https://doi.org/10.5296/ijld.v2i1.1470

İşeri, K. \& Ünal, E. (2012). Türkçe Öğretmen Adaylarının Yazma Kaygı Durumlarının Çeşitli Değişkenler Açısından İncelenmesi. Mersin University Journal of the Faculty of Education, $8(2), 67-76$.

Karasar, N. (2000). Bilimsel Araştırma Yöntemi. (10.bask1). Ankara: Nobell yayınc1lık.

Korkmaz, M., Aras, G., Çelebi, N., \& Gürkan, A. (2015). A study on the factors affecting university students reading habits. International Journal of Family, Child and Education, 5(3), 1-19. https://doi.org/10.17359/ACED.2015510150

Kubis, M. (1996). The relationship between home literary environments and attitudes toward reading in ninthgraders. ERIC Document Reproduction Service No. ED 385 822. Retrieved from www.eric.ed.gov/ERICWebPortal/recordDetail?accno=ED385822.

Odabaş, H., Odabaş, Z. Y., \& Polat, C. (2008). Üniversite öğrencilerinin okuma alışkanlığı: Ankara Üniversitesi örneği. Bilgi Dünyası, 9(2), 431-465.

Owusu-Acheaw, M. (2014). Reading Habits Among Students and its Effect on Academic Performance: A Study of Students of Koforidua Polytechnic. Library Philosophy and Practice (e-journal). http://digitalcommons.unl.edu/libphilprac/1130

Palani, K. K. (2012). Promising Reading Habits and Creating Literate Social. International Reference Research Journal, 3(2), 91.

Sağlam, M., Suna, Ç., \& Çengelci, T. (2007). Sınıf Öğretmenliği ile Diğer Öğretmenlik Programları Öğrencilerinin Okuma Alışkanlığı Düzeylerinin Karşılaştırılması. VI. Ulusal Sinıf Öğretmenliği Sempozyumu, 27-29 Nisan 2006, Eskişehir, 325-328.

Semerci, Ç. (2002). Türk üniversitelerinde Beden Eğitimi ve Spor bölümü öğrencilerinin okuma alışkanlıkları. Eğitim ve Bilim, 27, 36-43.

Solmaz, M. (2018). A study about reading habits of university student: Sampling of Yüzüncü 
Y1l University. Türkiye Sosyal Araştırmalar Dergisi, 603-622.

Temizkan, M., \& Sallabaş, M. E. (2009). Öğretmen adaylarının okuma ve yazmaya yönelik tutumlarının karşılaştırılması. Elektronik Sosyal Bilimler Dergisi, 8(27) 155-176. Retrieved from http://dergipark.org.tr/esosder/issue/6141/82407

Turcan, A. İ., Yıldırım, S. S., \& Kelleci, F. (1999). Üniversite öğrencileri arasında ders dışı okuma alışkanlık düzeyinin tesbiti üzerine bir araştırma. 4.Ulusal Eğitim Bilimleri Kongresi Bildirileri I. Eskişehir: Anadolu Üniversitesi.

Yaylal1, M. (2006). Üniversite gençliğinin sosyo-ekonomik profili araştırmast. Erzurum: Atatürk Üniversitesi Yayınları.

Yazıc1, E. (2001). Üniversite Gençliği, 2001: Üniversite gençliğinin sosyo-kültürel profili üzerine bir alan araştırması: Gazi Üniversitesi örneği. Ankara: Gazi Üniversitesi Yazyınları.

Yılmaz, B. (1993). Okuma alışkanlı̆̆ında halk kütüphanelerinin rolü. Ankara: Kültür Bakanlı̆̆ı.

\section{Copyright Disclaimer}

Copyright reserved by the authors.

This article is an open-access article distributed under the terms and conditions of the Creative Commons Attribution license (http://creativecommons.org/licenses/by/3.0/). 